\title{
Wkład środowiska wielkopolskiego w rozwój patrologii
}

Patrologia w Polsce zaczęła znacząco rozwijać się już w okresie międzywojennym. Przyczyniło się do tego w znacznym stopniu naukowe środowisko wielkopolskie skupione wokół Uniwersytetu Poznańskiego. Badacze wczesnochrześcijańskiego piśmiennictwa związani z tym regionem Polski mieli niewątpliwie ogromny wpływ na dalsze losy patrologii, zwłaszcza w powojennej historii naszej Ojczyzny. Powstałe w tym środowisku monografie, artykuły, przekłady pism Ojców Kościoła przyczyniły się bez wątpienia do podniesienia rangi wielkopolskiego ośrodka naukowego. Można też mówić o sprzyjającym klimacie, jaki stworzyli badacze wczesnochrześcijańskiego piśmiennictwa dla dalszych badań podejmowanych w tym kierunku.

Celem niniejszego opracowania jest przestudiowanie wspomnianego fenomenu patrystycznego, z jakim mamy do czynienia w Wielkopolsce w ostatnim stuleciu. Dlatego też przyjrzymy się najpierw najważniejszym osobom, które działały w tym regionie na rzecz patrologii. Istotnym niewątpliwie przyczynkiem do rozwoju patrologii w Polsce stały się serie wydawnicze związane ze środowiskiem wielkopolskim, które propagowały myśl wczesnochrześcijańską, zwłaszcza dzięki wydawanym przekładom pism Ojców Kościoła. Obrazem rozwoju każdej dyscypliny naukowej są też podręczniki akademickie, które w czasach powojennych, gdy brakowało opracowań naukowych, stanowiły dla studentów nieodzowną pomoc w przyswajaniu wiedzy. Wielkopolskie środowisko było pionierem pod względem podręczników do studiowania patrologii. Dzięki wysiłkom minionych pokoleń stało się możliwe powołanie Wydziału Teologicz-

\footnotetext{
${ }^{1}$ Ksiądz Bogdan Czyżewski - prezbiter archidiecezji gnieźnieńskiej, profesor nauk teologicznych, wykładowca patrologii, historii Kościoła starożytnego i języków klasycznych na Wydziale Teologicznym Uniwersytetu im. Adama Mickiewicza w Poznaniu, autor wielu publikacji naukowych z zakresu patrologii; Kierownik Zakładu Teologii Historycznej WT UAM; Prezes Sekcji Patrystycznej; e-mail: czybo@amu.edu.pl. ORCID: 0000-0002-6040-5523.
} 
nego na Uniwersytecie im. Adama Mickiewicza w Poznaniu, w którym nadal są podejmowane badania nad doktryną wczesnochrześcijańską.

Temat związany z wkładem środowiska wielkopolskiego w rozwój patrologii nie został jeszcze gruntownie i całościowo opracowany ${ }^{2}$. Poza biogramami patrologów i historyków Kościoła działających w Wielkopolsce oraz artykułami, w których tylko ogólnie zajęto się wspomnianą problematyką̧3 , brakuje całościowego spojrzenia na ważną dziedzinę nauki, jaką jest patrologia, która w środowisku wielkopolskim ciągle przeżywa swój renesans.

\section{Patrologowie wielkopolscy}

Mówiąc o patrologach wielkopolskich, należy wskazać na cztery nazwiska: Jan Sajdak, ks. Józef Nowacki, ks. Bronisław Gładysz oraz ks. Ludwik Gładyszewski ${ }^{4}$. Nie chodzi jednak tutaj tylko o pochodzenie z Wielkopolski, co raczej o związanie pracy naukowej z Uniwersytetem Poznańskim. Trzeba też dodać, że żaden z nich nie był w sensie ścisłym patrologiem, o czym się przekonujemy podczas lektury ich biogramów. Mimo to znaczną część swojej pracy naukowej poświęcili na badanie literatury wczesnochrześcijańskiej, przyczynili się też do propagowania myśli patrystycznej, nie tylko w Poznaniu, ale w Polsce i w świecie.

Pierwszą, niezwykle zasłużoną dla patrologii postacią, był Jan Sajdak. Urodził się 22 lutego 1882 roku w Burzynie, niedaleko Tarnowa. Studia z zakresu filologii klasycznej, archeologii klasycznej i historii filozofii, zwłaszcza greckiej, oraz historii literatury polskiej, odbył na Wydziale Filozoficznym Uniwersytetu Jagiellońskiego w Krakowie. Ostatnie zaś lata poświęcił na zgłębianie patrologii, szczególnie Ojców Kościoła z IV wieku. Doktorat obronił na Uniwersytecie Jagiellońskim w Krakowie, tam też habilitował się w zakresie filologii klasycznej na podstawie rozprawy o rękopisach greckich na Monte Cassino De codicibus

\footnotetext{
${ }^{2}$ Przedłożone tutaj opracowanie jest poszerzoną i zmienioną wersją artykułu Wkład środowiska poznańsko-gnieźnieńskiego w badania nad literatura wczesnochrześcijańska autorstwa B. Czyżewskiego, który ukazał się dwadzieścia lat temu na łamach „Vox Patrum” 19 (1999) t. 36-77, s. $97-107$.

${ }^{3}$ Por. wykaz bibliografii, w której podane zostały wspomniane opracowania biogramów patrologów i historyków Kościoła.

${ }^{4}$ Świadomie pomijam w tym miejscu patrologów żyjących, którzy swoimi badaniami i pracą przyczynili się do rozwoju patrologii. Aby wszystkim oddać należną im uwagę, musielibyśmy poświęcić tej tematyce obszerną monografię. Przyjąłem też zasadę, że żyjący patrologowie z Wielkopolski zostaną wspomniani w punkcie dotyczącym Papieskiego Wydziału Teologicznego i Wydziału Teologicznego UAM. W tej części nie zostanie też omówiony ks. Szczepan Pieszczoch (1921-2004), ponieważ będzie o nim mowa w części dotyczącej podręczników do patrologii.
} 
Graecis in Monte Cassino ${ }^{5}$. Wykłady prowadził kolejno na trzech uniwersytetach: Jagiellońskim, Lwowskim i Poznańskim. Na Wydziale Filozoficznym Uniwersytetu Jagiellońskiego i na Uniwersytecie Lwowskim uczył filologii klasycznej, na tym drugim też otrzymał tytuł profesora nadzwyczajnego. Nie wolno zapomnieć o jeszcze jednej istotnej działalności Jana Sajdaka w tym okresie jego życia. Otóż uzyskał on w 1910 roku stypendium, które pozwoliło mu prowadzić badania nad rękopisami w największych i najbardziej znanych bibliotekach europejskich: we Włoszech, Szwajcarii, Paryżu, Londynie, Berlinie, Oxfordzie, Wiedniu i Monachium. Oprócz badań pogłębiał swoją wiedzę przez uczęszczanie na wykłady i seminaria 6 .

Ze wspomnianymi ośrodkami uniwersyteckimi wiązały się zainteresowania naukowe i prowadzone badania, które zaowocowały licznymi publikacjami. Pracując na Uniwersytecie Jagiellońskim, zajął się przede wszystkim twórczością św. Grzegorza z Nazjanzu. W roku 1914 Polska Akademia Umiejętności wydała w serii Meletemata patristica obszerna książke Sajdaka pt. Historia critica scholiastarum et commentatorum Gregorii Nazianzeni. Parias I: De codicibus scholiastarum et commentatorum Gregorii Nazianzeni. Jan Sajdak opublikował też kilka innych rozpraw poświęconych Grzegorzowi z Nazjanzu?. Z kolei we Lwowie zmienił kierunek badań i zajął się wydawaniem publikacji na temat literatury rzymskiej ${ }^{8}$.

${ }^{5}$ Rozprawę habilitacyjną opublikował jako tom 50 Rozpraw Wydziału Filologicznego Polskiej Akademii Umiejętności, Kraków 1913 (por. W. Steffen, Od filologii do patrologii (Jan Sajdak 1882-1967), „Poznańskie Studia Teologiczne” IX (2000), s. 131-144, tu: s. 134).

${ }^{6}$ Por. W. Steffen, Od filologii..., s. 132-134.

7 J. Sajdak, O bibliotekach rękopisów greckich na wschodzie, „Przegląd Polski” 48 (1914) 192,

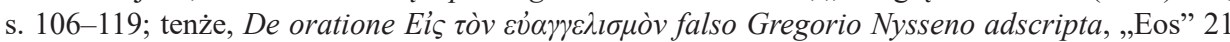
(1916); tenże, De Gregorio Nazianzeno poetarum Christianorum fonte, Kraków 1917; tenże, Quaestiones Nazianzenicae. Pars prima: Quae ratio inter Gregorium Nazianzenum et Maximum Cynicum intercedat, „Eos” 15 (1909), s. 18-48; tenże, De Gregorio Nazianzeno posteriorum rhetorum, grammaticorum, lexicographorum fonte, „Eos” 16 (1910), s. 94-99, 18 (1912), s. 1-30; tenże, Historia critica scholiastarum et commentatorum Gregorii Nazianzeni I, Kraków 1914; tenże, Die Scholiasten der Reden des Gregor von Nazianz, „Byzantinische Zeitschrift” 30 (1930), s. 268-274; tenże, Nazianzenica, „Eos” 15 (1909), s. 122-129, 16 (1910), s. 87-93; tenże, Rękopisy św. Grzegorza z Nazjanzu w bibliotekach szwajcarskich, „Eos” 17 (1911), s. 193-198; tenże, Anonymi Oxoniensis Lexicon in orationes Gregorii Nazianzeni, w: Symbolae grammaticae in honorem Joannis Rozwadowski, I, Cracoviae 1927, s. 153-177. Poza pracami poświęconym św. Grzegorzowi z Nazjanzu należy wymienić z tego okresu tegoż, De Cypriani epistularum codice Cracoviensi, „Eos” $20(1914 / 1915)$.

8 Tenże, Supplementum Rufinianum w "Sprawozdaniu Gimnazjum św. Jacka w Krakowie" (1918); tenże, Catullianum (carm. XLIX), „Eos” 23 (1918). W tym samym roku opublikował też w „Eos” trzy dotąd nieznane epigramy bliżej nieznanego bizantyjczyka Teodora na cześć Grzegorza z Nazjanzu. Krótki zarys historii filologii klasycznej w Polsce pt. Filologia klasyczna w Polsce, został opublikowany w tomie II zbiorowej pracy Polska w kulturze europejskiej, Kraków 1918. 
Kolejnym etapem jego naukowej działalności była praca na wspomnianym już Uniwersytecie Poznańskim (wcześniej nazywany Wszechnicą Piastowską). Zaproponowano Janowi Sajdakowi objęcie w Poznaniu katedry filologii klasycznej w charakterze profesora zwyczajnego. Profesor Sajdak przyjął zaproszenie i pojawił się w kwietniu 1919 roku na Uniwersytecie Poznańskim, gdzie urządził prawdziwy ośrodek filologiczny9. Pracę na uczelni rozpoczął od zorganizowania biblioteki filologii klasycznej. Zakupił zbiory, między innymi po zmarłych profesorach Schenklu z Wiednia i Klussmannie z Lipska. Dzięki temu stworzył największą w Polsce bibliotekę tej specjalności. Później poszerzył ją jeszcze o patrystykę i bizantynistykę, które zostały wyposażone w najnowsze wydawnictwa z tego zakresu ${ }^{10}$. Zgromadził około 30000 dzieł, na które złożyły się serie najnowszych czasopism filologicznych. Niestety, wspaniała biblioteka stworzona przez profesora Sajdaka spłonęła niemal doszczętnie pod koniec II wojny światowej ${ }^{11}$.

Profesor Sajdak jest twórcą tak zwanej poznańskiej szkoły filologicznej. W ciągu długich lat pracy na Uniwersytecie Poznańskim pełnił też liczne funkcje uniwersyteckie. Należy tutaj wspomnieć o tym, że był delegatem Rady Wydziału Filozoficznego do senatu uczelni i dziekanem Wydziału Filozoficznego. W roku akademickim 1931/32 pełnił funkcję rektora Uniwersytetu Poznańskiego, a rok później był jego prorektorem. Profesor Sajdak był także prezesem Komisji Egzaminacyjnej dla Kandydatów na Nauczycieli Szkół Średnich i Komisji Egzaminów Państwowych w Poznaniu na Nauczycieli Szkół Średnich oraz prezesem Komisji Egzaminów Magisterskich na Wydziale Humanistycznym. Niestety, w roku 1934, jako jeden z inicjatorów protestu brzeskiego, został przeniesiony w stan przymusowego spoczynku. Profesor Jan Sajdak postarał się jednak o wznowienie mu prawa wykładania na Uniwersytecie Jagiellońskim i przeniósł je na Uniwersytet Poznański, gdzie prowadził dalszą bezpłatną działalność dydaktyczną (bezpłatną, ponieważ formalnym powodem jego zwolnienia z Uniwersytetu Poznańskiego były trudności budżetowe uczelni). W Poznaniu założył też Collegium Marianum, którym kierował do czasu wybuchu wojny, a także zakład wychowawczy złożony ze szkoły powszechnej i gimnazjów męskiego i żeńskiego ${ }^{12}$.

Praca naukowa Jana Sajdaka w środowisku poznańskim koncentrowała się przede wszystkim wokół literatury bizantyjsko-greckiej. Stąd też jest autorem wielu prac poświęconych poecie, mówcy i filozofowi bizantyńskiemu z dziesiątego wieku, Janowi Geometresowi ${ }^{13}$. Brał też udział w kilku międzynarodowych

${ }^{9}$ Por. W. Steffen, Od filologii ..., s. 135-136.

${ }^{10}$ Por. B. Czyżewski, Wkład środowiska poznańsko-gnieźnieńskiego..., s. 98.

${ }^{11}$ Por. W. Steffen, Od filologii..., s. 136-137.

12 Por. B. Czyżewski, Wkład środowiska poznańsko-gnieźnieńskiego..., s. 98-99.

13 W 1920 roku J. Sajdak opublikował w „Eos” wiersz Geometresa Na cześć boskiego Dawida. Wydał też na temat Geometresa następujące prace: La poésie lyrique de Jan Geometres comme source historique, w: „VI-me Congrès International des Sciences Historiques”, Oslo 1928; Spicile- 
kongresach bizantynistów. Profesor Sajdak interesował się również literaturą grecką i rzymską ${ }^{14}$.

W 1923 roku poznański księgarz i wydawca Jan Jachowski zainicjował serię „Pisma Ojców Kościoła”, która była pierwszą polską patrystyczną serią thumaczeniową. Profesor Jan Sajdak, inspirator tego przedsięwzięcia, został redaktorem naczelnym serii i prowadził ją aż do 1949 roku. Wydał w niej ponad 20 tomów w polskich przekładach z obszernymi wstępami i objaśnieniami. Spośród tłumaczy należy wymienić ks. Arkadiusza Lisieckiego, ks. Jana Czuja, ks. Władysława Budzika, ks. Władysława Kubickiego, ks. Ludwika Wrzoła, Jana Stahra i Jana Ujdę. Osobiście Jan Sajdak przełożył we wspomnianej serii Oktawiusza Minucjusza Feliksa (tom 2, Poznań 1925) oraz Apologetyk Tertuliana (tom 20, Poznań 1949). Napisał też obszerną monografię Kwintus Septimiusz Florens Tertulian. Czasy - życie - dzieła (Poznań 1949). Dzieło to powstało w Tuchowie pod Tarnowem, gdzie Sajdak przebywał w czasie wojny, korzystając z tamtejszej biblioteki. W 1936 roku na specjalnej audiencji wręczył papieżowi Piusowi XI wydane tomy serii „Pisma Ojców Kościoła”. Była już ich wtedy pokaźna liczba osiemnastu ${ }^{15}$. Należy także wspomnieć o wykładzie inauguracyjnym wygłoszonym w Auli Uniwersytetu Poznańskiego z okazji otwarcia roku akademickiego 1931/32 na temat: Pedagogiczne poglady Grzegorza z Nazjanzu oraz o referacie: Studia patrystyczne w Polsce wygłoszonym w Poznaniu w 1931 roku $^{16}$.

Działalność Jana Sajdaka na płaszczyźnie patrologii związana jest również z tym, że był członkiem Komisji Filologicznej Akademii Umiejętności. Pełnił też funkcję sekretarza wchodzącego w skład tej komisji Komitetu do Wydawnictwa Greckich Ojców Kościoła IV wieku. Był członkiem Polskiej Akademii Umiejętności, Towarzystwa Naukowego we Lwowie, Poznańskiego Towarzystwa Przyjaciół Nauk, a także Bizantynistyki Polskiej Akademii Nauk. Należał również do Zarządu Towarzystwa Literackiego im. Adama Mickiewicza. Swój pracowity żywot profesor Jan Sajdak zakończył w Poznaniu 22 kwietnia 1967 roku ${ }^{17}$.

gium Geometreum I, II, „Eos” 32 (1929), s. 191-198; Co znaczy Geometres kyriotes, „Byzantion” 1931; Ioannis Geometrae hymni in SS. Deiparam, „Analecta Byzantina” 1, Poznaniae 1931; Ioannes Geometres quatenus feratur paraphrasis Canticorum secundum codicem Paris. Gr. 2743 traditae, „Eos” 1932/33; Literatura bizantyńska, w: Wielka literatura powszechna, t. IV, Warszawa 1933, s. 681-760; Bizantynistyka. Źródła i zarys studiów, Poznań 1933.

${ }_{14}$ Tenże, Franciszek Zabłocki jako tlumacz Horacego, Poznań 1928; tenże, Piusowi XI. Wielkiemu Papieżowi w hołdzie, Poznań 1939: Papież Wielki, s. 31-40; Pius XI jako uczony, s. 5961; Bibliografia prac i rozpraw naukowych ks. Achillesa Ratti, s. 61-64.

15 Por. B. Czyżewski, Wkład środowiska poznańsko-gnieźnieńskiego..., s. 99.

16 Por. tamże, s. 100.

17 Por. R. Skręt, Sajdak Jan, w: Polski Słownik Biograficzny, tom 34, Wrocław-Kraków-Warszawa 1992-1993, s. 332-334, zob. także B. Czyżewski, Wkład środowiska poznańsko-gnieźnieńskiego..., s. 100 . 
Drugą postacią związaną ze środowiskiem wielkopolskim był ks. Józef Nowacki. Urodził się 19 września 1893 roku w Mroczy na Krajnie. Studiował w Seminarium Duchownym w Poznaniu i w Gnieźnie w latach 1913-1917. Po święceniach kapłańskich rozpoczął specjalizację na uniwersytecie w Münster. Tam dwa lata studiował historię Kościoła i filologię klasyczną. Po powrocie z Niemiec, w latach 1919-1921, studiował historię i filologię klasyczną na Uniwersytecie Poznańskim. Tutaj też otrzymał dyplom w zakresie filologii klasycznej i klasyczno-orientalnej, natomiast doktorat $\mathrm{z}$ teologii obronił na Uniwersytecie Jana Kazimierza we Lwowie. Tam, w roku 1938, przeprowadził habilitacje i został docentem ${ }^{18}$. W 1927 roku prymas August Hlond zamianował ks. Józefa Nowackiego profesorem nadzwyczajnym historii Kościoła i patrologii w Arcybiskupim Seminarium Duchownym w Poznaniu. Nieco później uczony otrzymał nominację na profesora zwyczajnego. Głównym przedmiotem jego zainteresowań była historia Kościoła, którą wykładał i w Gnieźnie, i w Poznaniu do 1961 roku. Prowadził też wykłady z patrologii w Poznaniu do 1964 roku, w Gnieźnie zaś do roku 1953, czyli do momentu rozdziału seminariów poznańskiego i gnieźnieńskiego (wcześniej doszło do rozdziału obu archidiecezji ${ }^{19}$ ).

Ze względu na to, że ks. Nowacki był w pierwszym rzędzie historykiem Kościoła, jego działalność pisarska i naukowa skupiała się wokół tej dyscypliny ${ }^{20}$. Napisał dwutomowe dzieło niezwykle ważne dla środowiska, w którym pracował, mianowicie Dzieje archidiecezji poznańskiej (Poznań 1959-1964, t. I-II). $\mathrm{Na}$ tym jednak nie poprzestał, ponieważ jest autorem wielu innych prac z zakresu historii, zwłaszcza zaś Kościoła w Wielkopolsce. Będąc wykładowcą patrologii, pragnął, aby kojarzyła się ona bardziej z historią antycznej myśli chrześcijańskiej niż ze zbiorem opracowań literackich użytecznych tylko dla apologety, kaznodziei czy wychowawcy. Z inspiracji ks. Józefa Nowackiego wykłady dla roczników młodszych (I i II) w Gnieźnie prowadził ks. Andrzej Wronka, a rok przed wojną ks. Michał Kozal. Czytano na wykładach po łacinie Męczeństwo świętych Perpetuy i Felicyty (Passio S.S. Perpetuae et Felicitatis), a po grecku teksty liturgiczne św. Jana Chryzostoma ${ }^{21}$. Uczeń ks. Nowackiego, ks. profesor

\footnotetext{
18 O „dziejach” habilitacji ks. J. Nowackiego zob. K.R. Prokop, Niedoszly zamyst habilitacji ks. Józefa Nowackiego na Wydziale Teologicznym Uniwersytetu Jagiellońskiego w świetle jego listów do ks. prof. Tadeusza Glemmy, ,Ecclesia. Studia z dziejów Wielkopolski” 7 (2012), s. 231-264.

19 Por. B. Czyżewski, Wkład środowiska poznańsko-gnieźnieńskiego..., s. 100-101. Więcej na temat działalności naukowej i dydaktycznej ks. Nowackiego zob. M. Banaszak, Ksiądz Józef Nowacki — historyk Kościoła w Polsce. Wspomnienie pośmiertne o działalności naukowej i pedagogicznej, w: J. Nowacki, Dzieje Archidiecezji Poznańskiej, t. 2, Poznań 1964, s. 967-974.

${ }^{20} \mathrm{O}$ twórczości naukowej ks. J. Nowackiego zob. A. Weiss, Nowacki Józef, „Encyklopedia katolicka", t. XIV, Lublin 2010, kol. 27-28.

${ }^{21}$ Por. S. Pieszczoch, Patrologia w Wielkopolsce, szczególnie w Gnieźnie, przed i po II wojnie światowej na tle sytuacji ogólnopolskiej, w: „Studia Gniesnensia” 11 (1997), s. 335-344, tu: s. 341; zob. także B. Czyżewski, Wkład środowiska poznańsko-gnieźnieńskiego..., s. 101.
} 
Szczepan Pieszczoch, w następujący sposób wspominał spotkania ze swoim profesorem patrologii:

Byliśmy zaszokowani jego erudycją historyczną. Zaciążyła ona nieco na przejrzystości wykładu, ale dała nam wyobrażenie o gigantycznym wysiłku myślowym ludzi tamtych czasów i to nie tylko wykształconych biskupów, kapłanów, mnichów a także laików, nie tylko filozofów i retorów, ale także prostych ludzi, głęboko wierzących i miłujących Zbawiciela. Klimat tego zaangażowania w apologiach, polemikach, był nieraz bardzo gorący. Przeciwnik-heretyk był czasem zbyt mocno traktowany, jako domniemany uczeń diabła. Wykłady Nowackiego więcej niż sam podręcznik pomagały nam zbliżyć się do zrozumienia tamtych ludzi i czasów²2.

Mówiąc o wkładzie księdza Nowackiego w badania nad literaturą wczesnochrześcijańską w Wielkopolsce, należy zaznaczyć, że dokonał on przekładu ważnego wówczas podręcznika Gerharda Rauschena Zarys patrologii, który ukazał się w Poznaniu w roku 1929 nakładem Księgarni św. Wojciecha. Ksiądz profesor Józef Nowacki zmarł 28 kwietnia 1964 roku w Poznaniu ${ }^{23}$.

Kolejną postacią związaną ze środowiskiem wielkopolskim był ks. Bronisław Gładysz, badacz łaciny średniowiecznej. Urodził się 3 września 1892 roku w Sierakowie w województwie poznańskim. Gimnazjum klasyczne ukończył w Gnieźnie, później kształcił się w Seminarium Duchownym w Poznaniu i Gnieźnie. Po święceniach kapłańskich był najpierw kapelanem wojskowym, później zaś proboszczem parafii św. Antoniego w Starołęce. W tym samym czasie studiował na Uniwersytecie Poznańskim. Tam obronił pracę doktorską z filozofii, po habilitacji natomiast został zatwierdzony w charakterze docenta Uniwersytetu Poznańskiego w zakresie średniowiecznej literatury łacińskiej. Prowadził działalność dydaktyczną, referował swoje prace w Komisjach Teologicznej i Filozoficznej Poznańskiego Towarzystwa Przyjaciół Nauk. Wydał drukiem 40 rozpraw, poza nimi liczne streszczenia, sprawozdania i recenzje. Publikacje ks. Gładysza dotyczyły przeważnie poetów chrześcijańskich: Seduliusza oraz Wenancjusza Fortunata. Poruszał w nich zagadnienia hymnografii, rymotwórstwa, łacińskiego dramatu średniowiecznego i hagiografiii ${ }^{24}$. Wśród najważniejszych publikacji ks. Gładysza można wymienić następujące prace: Dogmatyczne teksty w poetyckich utworach Seduliusza. Studium z historii dogmatów V wieku (Poznań 1930),

\footnotetext{
${ }^{22}$ S. Pieszczoch, Ksiądz Józef Nowacki jako patrolog, w: „Ecclesia posnaniensis”. Opuscula Mariano Banaszak septuagenario dedicata Universitatis Mickiewiczianae Facultas Theologica Posnaniae, Poznań 1998, s. 267-272, tu: s. 271-272.

${ }_{23}$ Por. B. Czyżewski, Wkład środowiska poznańsko-gnieźnieńskiego..., s. 102.

${ }^{24}$ Por. J. Dziech, Gładysz Bronisław Hieronim, w: Polski Słownik Biograficzny, t. 8, WrocławKraków-Warszawa 1959-1960, s. 7.
} 
Rzym w poezji Seduliusza ${ }^{25}$; Święty Augustyn u kolebki hymnografii łacińskiej ${ }^{26}$; De extremis quibus Seduliana carmina ornatur verborum syllabis inter se consonantibus (Leopoli 1931); Pierwiastki poklasyczne w traktacie Bedy „De arte metrica"27; Konstantyn Wielki we wspótczesnej mu poezji28; Cassiodore et l'organisation de l'Ecole Medievale ${ }^{29}$; Dzisiejsza hymnologia kościelna w swym historycznym rozwoju $u^{30}$. Przed drugą wojną światową w latach trzydziestych ukazywały się również w Kurierze Poznańskim oraz w Mysterium Christi artykuły autorstwa księdza Gładysza na temat hymnów Wenancjusza Fortunata ${ }^{31}$.

Z wymienionych wyżej tytułów wynika, że działalność naukowa ks. Gładysza nie była związana wyłącznie z Ojcami Kościoła. Można jednak w niej dostrzec zainteresowania idące $w$ kierunku badania literatury wczesnochrześcijańskiej. Ksiądz Bronisław Gładysz został aresztowany 18 lipca 1941 roku przez Gestapo, następnie był więziony w Poznaniu, potem we Wronkach, Zwickau, Rawiczu i Mauthausen-Gusen, gdzie zginął 19 czerwca 1943 roku $^{32}$.

Należy wspomnieć jeszcze o ks. Ludwiku Gładyszewskim, który urodził się 17 września 1932 roku w miejscowości Wysoka na Krajnie. Po ukończeniu gimnazjum ogólnokształcącego w Nakle nad Notecią wstąpił do Arcybiskupiego Seminarium Duchownego w Gnieźnie. Święcenia kapłańskie przyjął w 1957 $\mathrm{roku}^{33}$. W 1958 roku został skierowany na studia z zakresu filologii klasycznej w Katolickim Uniwersytecie Lubelskim. Ukończył je w 1963 roku. Złożył wymagany egzamin magisterski i napisał pod kierunkiem prof. Leokadii Małunowiczówny pracę magisterską pt. „Wyrażenia przenośne określające życie, śmierć i szczęśliwość wieczną u św. Ambrożego"34. Od 1963 roku prowadził wykłady z zakresu filologii klasycznej w Prymasowskim Wyższym Seminarium Duchownym w Gnieźnie. Nauczał języka łacińskiego i greckiego, a także dodatkowo języka polskiego, prowadząc konwersatorium o literaturze katolickiej, a przez kilka lat uczył także języka niemieckiego. Pracę doktorską napisał pod kierunkiem ks. prof. Mariana Kurdziałka na Wydziale Filozoficznym KUL. Temat dysertacji brzmiał: Bóg Stwórca i Wtadca. Doktryna greckich apologetów II w. o stworze-

25 Por. „Kwartalnik Klasyczny” 3 (1929), s. 73-84.

26 Por. „Przegląd Teologiczny” 11 (1930), s. 371-398.

27 Por. „Sprawozdania Poznańskiego Towarzystwa Przyjaciół Nauk” 7 (1933), s. 3-5.

28 Por. CT 18 (1937), s. 63-100

29 Por. CT 17 (1936), s. 15-69.

${ }^{30}$ Por. AK 18 (1932) t. 30, s. 366-377.

31 Por. B. Czyżewski, Wkład środowiska poznańsko-gnieźnieńskiego..., s. 102-103.

${ }^{32}$ Por. tamże.

${ }^{33}$ Por. Kanonicy Kapituly Katedry Gnieźnieńskiej 1918-2009, red. B. Czyżewski, K. Wętkowski, Gniezno 2010, s. 319.

${ }^{34}$ Por. B. Czyżewski, Ks. dr Ludwik Gładyszewski (17 IX 1932 - 19 XII 2009). Prawdziwy miłośnik antyku chrześcijańskiego i filologii klasycznej, „Vox Patrum” 29 (2009) 53-54, s. 1105 1108, tu: s. 1106. 
niu i opatrzności w aspekcie historyczno-filozoficznym. Został mianowany profesorem nadzwyczajnym (1971 r.), następnie zaś, po dłuższym okresie pracy, profesorem zwyczajnym seminarium duchownego (1979 r.). Te stanowiska były z nadania arcybiskupa gnieźnieńskiego, aby podkreślić rangę uczących w seminarium duchownym. Nie miały one jednak nic wspólnego z uzyskiwanymi stopniami naukowymi ${ }^{35}$.

Praca naukowa ks. dra Ludwika Gładyszewskiego była związana nie tylko z dydaktyką. Należy bowiem wspomnieć o Zakładzie Badań nad Antykiem Chrześcijańskim przy Katolickim Uniwersytecie Lubelskim, z którym długi czas pozostawał w kontakcie. Przygotowywał dla niego do druku materiały zbierane jeszcze przez prof. Leokadię Małunowiczównę, był też redaktorem dwóch tomów serii: „Starożytne teksty chrześcijańskie”36.

Nie zdołał, niestety, zrealizować swego wielkiego marzenia o zrobieniu habilitacji. Były to początkowo przeszkody natury dydaktycznej, ponieważ duża liczba godzin wykładowych uniemożliwiła mu znalezienie czasu na poświęcenie się pisaniu książki habilitacyjnej. Później zaś choroba kazała mu zrezygnować z podjęcia tego zadania. Mógł jednak poszczycić się poczynionymi przygotowaniami do pracy habilitacyjnej. W tym celu przetłumaczył z języka greckiego, opracował i opublikował pięć homilii maryjnych Hezychiusza z Jerozolimy ${ }^{37}$, przełożył też i opracował grecką homilię Eis hypapanten o tej samej tematyce Amfilochiusza z Ikonium. Jest też autorem licznych artykułów z zakresu patrologii ${ }^{38}$. Niewątpliwie ważnym jego dokonaniem były tłumaczenia z języków klasycznych, najczęściej łacińskiego, na język polski dzieł Ojców Kościoła ${ }^{39}$.

\footnotetext{
${ }^{35}$ Por. tenże, Ksiadz Ludwik Gładyszewski (1932-2009). Filolog klasyczny, tlumacz i badacz antyku chrześcijańskiego, „Teologia Patrystyczna” 7 (2010), s. 9-32, tu: s. 12-14.

${ }^{36}$ Por. B. Czyżewski, Ksiadz Ludwik Gtadyszewski..., s. 16.

${ }^{37}$ L. Gładyszewski, Maryjne homilie Hezychiusza z Jerozolimy, przekład, wstęp, opracowanie, SG 4 (1978), s. 175-207; tenże, Chrystologiczna czy maryjna homilia Hezychiusza, przekład, wstęp, opracowanie, SG 5 (1979-80), s. 245-268.

${ }^{38}$ Por. wykaz całego dorobku naukowego ks. L. Gładyszewskiego w: B. Czyżewski, Ksiądz Ludwik Gtadyszewski..., s. 20-29.

${ }^{39}$ Kazania i homilie na święta Pańskie i Maryjne, „Starożytne teksty chrześcijańskie”, t. 1, wstęp, przekłady i redakcja, Lublin 1976; List „O przeznaczeniu” Andronika Trankwillusa Dalmaty, SG 2 (1976), s. 281-295; św. Atanazy, List do Amuna, List do Drakontiosa, „Antologia Listu Starożytnego", t. 2, Lublin 1978, s. 65-73; Rufina katecheza Symbolu, wstęp, przekład, przypisy, SG 6 (1981), s. 9-64; św. Cezary z Arles, Pascha Chrystusa, fragment kazania i komentarz, „Odpowiedzialność” 4 (1991), s. 4; tenże, Homilia o poście, tłumaczenie i komentarz, „Odpowiedzialność" 3 (1992), s. 11; L. Małunowiczówna, Antologia modlitwy wczesno-chrześcijańskiej (ukonczył pracę i przygotował do druku), Lublin 1993; św. Grzegorz Wielki, Moralia. Komentarz do Księgi Hioba, t. 2, księgi VI-X, (tłumaczenie księgi VII, 77-141), ŹrMon 41, Kraków 2006; Augustyn, Piotr Chryzolog, Wenancjusz Fortunatus, Symbol Apostolski w nauczaniu Ojców, thumaczenie, wstępy i objaśnienia, ŹMT 53, Kraków 2010.
} 
Szczególnie ulubioną przez niego osobą był biskup Mediolanu, św. Ambroży ${ }^{40}$. Niemałym też sentymentem darzył św. Hieronima ze Strydonu ${ }^{41}$. Przełożył bowiem jego Komentarz do starotestamentalnej Księgi Jonasza ${ }^{42}$. Prowadził też seminarium magisterskie, wypromował 36 magistrantów. Zmarł nagle, w czasie obiadu, w dniu inauguracji posługi prymasowskiej abpa Henryka Muszyńskiego, 19 grudnia 2009 roku w 78 roku życia.

\section{Serie wydawnicze}

Wkładem środowiska wielkopolskiego w badania nad literaturą wczesnochrześcijańską jest znana seria wydawnicza „Pisma Ojców Kościoła”. Zainicjował ją wspomniany już profesor Jan Sajdak. Pierwszy tom z tej serii, nakładem Księgarni Uniwersyteckiej, ukazał się w roku 1924. Był to przekład Pism Ojców Apostolskich dokonany przez ks. Arkadiusza Lisieckiego. Do roku 1939, czyli do wybuchu II wojny światowej, ukazało się we wspomnianej serii 20 tomów przekładów pism literatury wczesnochrześcijańskiej. Oprócz Pism Ojców Apostolskich były to następujące teksty patrystyczne opatrzone zawsze wstępem i komentarzami: Oktawiusz Minucjusza Feliksa, Historia kościelna, O męczennikach palestyńskich Euzebiusza z Cezarei ${ }^{43}$, dwie Apologie i Dialog z Żydem Tryfonem św. Justyna, Boecjusza $O$ pociechach Filozofji ksiag pięcioro, Traktaty teologiczne, Rozmowy św. Jana Kasjana, Pamiętniki-commonitorium św. Wincentego z Lerynu, Wyznania, Pisma katechetyczne i Państwo Boże św. Augustyna, Wiktora z Wity Dzieje prześladowania Kościoła w Afryce przez Wandalów, Listy św. Grzegorza z Nazjanzu, Kazania wybrane św. Leona Wielkiego, Pisma wybrane Laktancjusza, niektóre pisma apologetów greckich II wieku, kilka pism św. Cypriana z Kartaginy oraz Mowy św. Ambrożego z Mediolanu ${ }^{44}$.

Po II wojnie światowej seria „Pisma Ojców Kościoła” wznowiła działalność, która trwała do roku 1971. Niestety, ze względu na trudności wydawnicze, które dotykały wszystkie katolickie wydawnictwa w czasach komunizmu, wydano tyl-

\footnotetext{
40 Św. Ambroży, Wybór pism dogmatycznych, przekład i przypisy, POK t. 26, Poznań 1970; św. Ambroży z Mediolanu, Wyjaśnienie symbolu. O tajemnicach. O sakramentach, przekład, wstęp i opracowanie, ŹMT t. 31, Kraków 2004.

${ }^{41}$ Św. Hieronim, Na Narodzenie Pana, thumaczenie i komentarz, „Odpowiedzialność” 1 (1992), s. 6.

${ }^{42}$ Św. Hieronim, Komentarz do Księgi Jonasza, ŹMT t. 8, wstęp patrystyczny, przekład, opracowanie, Kraków 1998.

${ }^{43}$ Historia kościelna Euzebiusza z Cezarei doczekała się w 1993 roku tylko przedruku przez Wydawnictwo Apostolstwa Modlitwy w Krakowie. Wydanie natomiast z roku 2013 wraz z tekstem greckim (ŹMT, t. 70) zostało oparte na podstawie tłumaczenia ks. Arkadiusza Lisieckiego.

${ }^{44}$ Por. W. Stawiszyński, Bibliografia patrystyczna 1901-2004. Polskie thumaczenia tekstów starochrześcijańskich pierwszego tysiąclecia, Kraków 2005, s. 21-22.
} 
ko siedem tomów. W roku 1947 ukazał się jako pierwszy tom po wojnie Apologetyk Tertuliana. Później zaś Księga reguły pasterskiej św. Grzegorza Wielkiego, dialog O kapłaństwie św. Jana Chryzostoma, Mowy św. Leona Wielkiego, Wybór pism dogmatycznych św. Ambrożego oraz O Trójcy Świętej i Traktaty o łasce św. Augustyna ${ }^{45}$. Podobnie jak thumaczenia przedwojenne, te również miały wstępy i komentarze ${ }^{46}$.

W omawianej serii od 1924 do 1971 roku wydano 27 tomów (tomy od 1 do 23 wydawane były przez Księgarnię Uniwersytecką w Poznaniu, a wydawcą był Jan Jachowski, tomy od 24 do 27 były kontynuowane przez Księgarnię św. Wojciecha w Poznaniu). Musimy też zaznaczyć, że niektóre z tych tomów doczekały się reprintów opublikowanych przez Wydział Teologiczny UAM. Wspomniana seria, mimo wieloletniej przerwy, została wznowiona i od 28 tomu wydawana jest przez Wydział Teologiczny Uniwersytetu im. Adama Mickiewicza w Poznaniu. Ukazały się następujące przekłady pism wczesnochrześcijańskich autorów: O widowiskach. O batwochwalstwie Tertuliana (t. 28), Pisma dogmatyczne i egzegetyczne św. Cezarego z Arles (t. 29), Peristeria. Traktat dla mnicha Agatiusa Nila z Ancyry (t. 30), O Duchu Świętym św. Ambrożego z Mediolanu (t. 31), Żywot Cezarego z Arles spisany przez uczniów (t. 32), Ildefonsa z Toledo Pouczenie o chrzcie (t. 33) ${ }^{47}$.

Wśród tłumaczy serii „Pisma Ojców Kościoła” powtarzają się przede wszystkim trzy nazwiska: ks. Jan Czuj, który przełożył osiem tomów, dalej ks. Arkadiusz Lisiecki (trzy tomy) oraz Jan Sajdak (dwa tomy). Tomy najnowsze, wydawane przez Wydział Teologiczny UAM, thumaczone były przez Annę Strzelecką (cztery tomy), Stefana Naskręta (jeden tom) i Leona Nieściora (jeden tom). Do trzech z nich wstęp napisał ks. Paweł Wygralak.

Ocena serii „Pisma Ojców Kościoła” musi uwzględniać możliwości, jakie istniały przed wojną i po jej zakończeniu. Było to przedsięwzięcie ogromne, zasługujące z całą pewnością na uznanie. Niektóre z tomów zaopatrzono w dobre indeksy, wartościowe wstępy i przypisy ułatwiające zrozumienie thumaczonych tekstów. Należy również zaznaczyć, że przed wojną była to w Polsce jedyna seria zawierająca thumaczenia dzieł niektórych pisarzy wczesnochrześcijańskich. Jej popularność nie była jednak zbyt duża, o czym świadczy spis prenumeratorów sporządzony przez przedwojennego wydawcę Jana Jachowskiego. Podaje on, że do 1937 roku było 198 abonentów tej serii, natomiast w 1939 roku tylko 178 . $\mathrm{Na}$ tej liście znalazło się 10 biskupów, 10 seminariów duchownych, 14 domów zakonnych i 25 osób świeckich ${ }^{48}$.

${ }^{45}$ Por. tamże, s. 22.

46 Por. B. Czyżewski, Wkład środowiska poznańsko-gnieźnieńskiego..., s. 104.

${ }^{47}$ Por. W. Stawiszyński, Bibliografia patrystyczna ..., s. 22.

${ }^{48}$ Por. S. Pieszczoch, Patrologia w Wielkopolsce..., s. 337. 
Mówiąc o seriach wydawniczych, jakie ukazywały się w środowisku wielkopolskim, należy wymienić jeszcze „Starożytną Myśl Chrześcijańską” pod redakcją ojca profesora Jana Marii Szymusiaka SJ, zainaugurowaną przez Wydawnictwo św. Wojciecha. W wymienionej serii ukazały się tylko dwa tomy: Grzegorz Teolog. U źródet chrześcijańskiej myśli IV wieku autorstwa wspomnianego wyżej ojca J.M. Szymusiaka (1965), drugi w 1971 roku: Stownik wczesnochrześsijańskiego piśmiennictwa tegoż autora i ks. Marka Starowieyskiego, który doczekał się wznowienia i uzupełnienia w roku 2018 i nosi tytuł: Nowy słownik wczesnochrześcijańskiego piśmiennictwa. W tej serii nie ukazywały się tłumaczenia pism Ojców. Chociaż książka Grzegorz Teolog zawiera przekład niektórych Mów i Poematów św. Grzegorza z Nazjanzu, należy jednak bardziej do opracowań teologicznych. Z kolei Stownik wczesnochrześcijańskiego piśmiennictwa i Nowy stownik wczesnochrześcijańskiego piśmiennictwa są zestawami biografii świadków tradycji chrześcijańskiej od czasów apostolskich do chwili pierwszej stabilizacji świata europejskiego po wstrząsach wędrówki ludów na Zachodzie (VIII w.), a na Wschodzie do II Soboru Nicejskiego (787 r.) $)^{49}$.

Nie można zapomnieć o jeszcze jednej ważnej serii, mianowicie o „Teologii Patrystycznej" wydawanej przez Wydział Teologiczny Uniwersytetu im. Adama Mickiewicza w Poznaniu. Do tej pory ukazało się 15 jej tomów (ostatni w roku 2018). Zawierają one artykuły i monografie o tematyce patrystycznej oraz przekłady pism autorów wczesnochrześcijańskich. Publikują w tej serii nie tylko patrolodzy wielkopolscy, ale także autorzy reprezentujący inne polskie uczelnie.

\section{Podręczniki do patrologii}

Ze środowiskiem wielkopolskim związane są także podręczniki patrologii. Pierwszym z nich było wspomniane już tłumaczenie ks. Józefa Nowackiego na język polski Grundriss der Patrologie Gerharda Rauschena z poprawionego i uzupełnionego przez Josefa Wittiga. Ksiądz Nowacki dokonał przekładu z ósmego i dziewiątego wydania tego podręcznika (z roku 1926), co świadczy o jego wielkiej popularności. Podręcznik ten nosił tytuł Zarys patrologii. Pisma Ojców Kościoła i nauka w nich zawarta, a ukazał się w roku 1929 nakładem Księgarni św. Wojciecha w Poznaniu ${ }^{50}$.

Kolejnym, ale już powojennym podręcznikiem, była Patrologia. Wprowadzenie w studium Ojców Kościoła autorstwa ks. Szczepana Pieszczocha ${ }^{51}$. Ukazała

49 Por. B. Czyżewski, Wkład środowiska poznańsko-gnieźnieńskiego..., s. 104.

${ }^{50}$ Por. tamże, s. 105.

${ }^{51}$ Ks. Szczepan Pieszczoch należy także do grona zasłużonych patrologów Wielkopolski. Tutaj wspominam tylko o jego podręcznikach, co w całym dorobku naukowym tego autora było najważ- 
się w 1964 roku, a wydana została przez Księgarnię św. Wojciecha w Poznaniu. Podręcznik ten składał się z trzech podstawowych części. Pierwsza, zatytułowana Prolegomena patrystyczne, zawierała wprowadzenie teologiczne, ze szczególnym uwzględnieniem problemu tradycji. W drugiej części: Zarys patrologii, zostały omówione początki literatury patrystycznej oraz rozwój teologii patrystycznej aż do św. Izydora z Sewilli i św. Jana Damasceńskiego. Ta część podręcznika ks. Pieszczocha kończyła się krótkim zarysem historii teologii popatrystycznej. Należy jeszcze dodać, że w drugiej części znajdował się także wybór zwięzłych tekstów źródłowych. Część trzecia: Pomoce do dalszego samodzielnego studium Ojców Kościoła, zawierała bibliografię głównych pozycji literatury patrystycznej oraz ówczesne aktualności patrologiczne. Podręcznik ks. Pieszczocha używany był przez długie lata jako pomoc w poznawaniu pisarzy kościelnych okresu patrystycznego, zwłaszcza w seminariach duchownych. W okresie powojennym, oprócz Patrologii ks. Jana Czuja dwukrotnie wydanej również w Poznaniu w roku 1953 i 1954, nie było innego podręcznika do tej dyscypliny w języku polskim ${ }^{52}$.

Na tym jednak podręczniku ks. Pieszczoch nie poprzestał, ponieważ w roku 1994 przepracował swoją pierwszą Patrologię i wydał ją w dwóch tomach w gnieźnieńskim wydawnictwie Gaudentinum. Pierwsza część zatytułowana: Działalność Ojców, to przede wszystkim prezentacja dorobku ważniejszych autorów antyku chrześcijańskiego do VIII wieku, zakończona materiałami uzupełniającymi, wśród nich zaś najważniejsza wydaje się Polskojęzyczna bibliografia antyku chrześcijańskiego za lata 1900-1993 i Polskie wydawnicze serie patrystyczne opracowane przez ks. dra Stanisława Longosza (ss. 201-280 + I-XXIV). Drugi tom wspomnianego podręcznika nosi tytuł: Ojcowie mówia i zawiera wybrane teksty autorów omówionych w części pierwszej. Trzecie wydanie podręcznika ks. Szczepana Pieszczocha Patrologia, tym razem w jednej części (ss. 414), ukazało się w 1998 roku $^{53}$.

\section{Wydziały Teologiczne}

Patrologia nie mogłaby być skutecznie uprawiana w środowisku wielkopolskim bez Wydziału Teologicznego. Najpierw znalazła się w programie studiów Papieskiego Wydziału Teologicznego w Poznaniu założonego w 1969 roku. Do tego

niejsze. Więcej na temat ks. Pieszczocha i jego działalności naukowej zob. B. Czyżewski, Ksiądz Szczepan Pieszczoch (1921-2004) — człowiek, który prawdziwie kochat Ojców Kościoła, „Vox Patrum" 24 (2004) 46-47, s. 893-898.

${ }_{52}$ Por. B. Czyżewski, Wkład środowiska poznańsko-gnieźnieńskiego..., s. 105.

53 Por. tamże. 
wydziału afiliowane zostały seminaria duchowne diecezji gnieźnieńskiej, gdańskiej, a potem szczecińskiej i koszalińsko-kołobrzeskiej, oraz zakonne: Oblatów Maryi Niepokalanej, Misjonarzy św. Rodziny i Karmelitów Bosych. Należały do niego też Instytuty dla świeckich działające w Gnieźnie, Bydgoszczy i Koszalinie. Na Papieskim Wydziale Teologicznym, staraniem ks. profesora Bogdana Częsza, istniał Instytut Teologii Patrystycznej i Starożytności Chrześcijańskiej, którego kierownikiem był jego założyciel. Papieski Wydział Teologiczny umożliwiał klerykom i studentom świeckim zdobywanie tytułów i stopni naukowych, w tym także z patrologii. W ciągu 29 lat istnienia Papieskiego Wydziału Teologicznego obroniono wiele prac magisterskich z patrologii, a także licencjackich i doktorskich ${ }^{54}$.

Od 1 grudnia 1998 roku istnieje Wydział Teologiczny Uniwersytetu im. Adama Mickiewicza w Poznaniu, w ramach którego do roku 2015 działał Zakład Teologii Patrystycznej, do chwili obecnej zaś Zakład Teologii Patrystycznej i Historii Kościoła. W początkowym okresie liczył on dwóch profesorów (ks. Bogdan Częsz - teologia patrystyczna; ks. Antoni Swoboda - starożytna literatura chrześcijańska), ośmiu adiunktów oraz jednego starszego wykładowcę ${ }^{55}$. Obecnie zaś liczy czterech profesorów (ks. Bogdan Czyżewski, ks. Michał Kieling, o. Piotr Neumann OCD, ks. Paweł Wygralak) oraz jednego adiunkta z tytułem doktora habilitowanego (o. Paweł Zając OMI). Wymienieni pracownicy prowadzą działalność naukową i dydaktyczną. Wykłady, seminaria naukowe z patrologii i historii Kościoła dla duchownych, kleryków i świeckich, liczne publikacje w formie książek i artykułów, to owoc pracy patrologów wielkopolskich i ich wkład w rozwój tej jakże ważnej dziedziny naukowej.

Patrząc z perspektywy 100 lat, należy jednoznacznie stwierdzić, że patrologia w Wielkopolsce nie należy do zapomnianych, ale kontynuowany jest dorobek wielkich poprzedników związanych kiedyś z Uniwersytetem Poznańskim, obecnie zaś z Uniwersytetem im. Adama Mickiewicza w Poznaniu. Dzięki ich pracy i staraniom bogaty dorobek pierwszych wieków Kościoła jest coraz bardziej rozpowszechniany i przybliżany następującym po sobie pokoleniom.

${ }_{54}^{54}$ Por. tamże, s. 105-106.

${ }^{55}$ Por. tamże, s. 106. 


\section{Contribution of the Wielkopolska environment to the development of patrology}

\section{Summary}

The proposed topic allows to learn about the scientific activity of the Wielkopolska researchers of the early Christian Church: Jan Sajdak (1882-1967), priest Józef Nowacki (1893-1964), priest Bronisław Gładysz (1892-1943) and priest Ludwik Gładyszewski (1932-2009). They contributed to the development of patristics not only in Wielkopolska, but also in Poland and in the world. Wielkopolska is also associated with the Scriptures of the Fathers of the Church in which translations of writers of the first centuries of Christianity are published. Patrology textbooks have also been published. The most important of them was written by the priest Szczepan Piestoch and is intended especially for students of theology. Wielkopolska is also a Faculty of Theology which has been operating since 1998 at the University of Adam Mickiewicz University in Poznań. It includes the Department of Patristic Theology and currently the Department of Patristic Theology and Church History. Under the supervision of the faculty lecturers doctoral theses, master's and bachelor's theses, as well as monographs related to the period of Christian antiquity are prepared.

\section{Keywords}

Wielkopolska, patrology, Fathers of the Church, textbooks, Faculty of Theology

\section{Slowa kluczowe}

Wielkopolska, patrologia, Ojcowie Kościoła, podręczniki, Wydział Teologiczny

\section{Zestawienie zastosowanych skrótów}

$$
\begin{aligned}
& \text { AK - Ateneum Kapłańskie } \\
& \text { CT - Collectanea Theologica } \\
& \text { POK - Pisma Ojców Kościoła } \\
& \text { SG - Studia Gnesnensia } \\
& \text { ŹMT - Źródła Myśli Teologicznej } \\
& \text { ŹrMon - Źródła Monastyczne }
\end{aligned}
$$

\section{Bibliografia}

Ambroży św., Wybór pism dogmatycznych, przekład i przypisy L. Gładyszewski, POK, t. 26, Poznań 1970.

Ambroży z Mediolanu św., Wyjaśnienie symbolu. O tajemnicach. O sakramentach, przekład, wstęp i opracowanie, ŹMT, t. 31, Kraków 2004. 
Atanazy św., List do Amuna, List do Drakontiosa, tłum. L. Gładyszewski, „Antologia Listu Starożytnego", t. 2, Lublin 1978, s. 65-73.

Augustyn, Piotr Chryzolog, Wenancjusz Fortunatus, Symbol Apostolski w nauczaniu Ojców, tłumaczenie, wstępy i objaśnienia ks. Ludwik Gładyszewski, ŹMT 53, Kraków 2010.

Banaszak M., Ksiądz Józef Nowacki - historyk Kościoła w Polsce. Wspomnienie pośmiertne o działalności naukowej i pedagogicznej, w: J. Nowacki, Dzieje Archidiecezji Poznańskiej, t. 2, Poznań 1964, s. 967-974.

Cezary z Arles, Homilia o poście, tłumaczenie i komentarz L. Gładyszewski, „Odpowiedzialność" 3 (1992), s. 11.

Cezary z Arles św., Pascha Chrystusa, fragment kazania i komentarz L. Gładyszewski, „Odpowiedzialność” 4 (1991), s. 4.

Czyżewski B., Ksiadz Ludwik Gładyszewski (1932-2009). Filolog klasyczny, ttumacz i badacz antyku chrześcijańskiego, „Teologia Patrystyczna” 7 (2010), s. 9-32.

Czyżewski B., Ksiądz Szczepan Pieszczoch (1921-2004) — człowiek, który prawdziwie kochat Ojców Kościoła, „Vox Patrum”, 24 (2004) 46-47, s. 893-898.

Czyżewski B., Ks. dr Ludwik Gładyszewski (17 IX 1932 - 19 XII 2009). Prawdziwy miłośnik antyku chrześcijańskiego i filologii klasycznej, „Vox Patrum” 29 (2009) 53-54, s. $1105-1108$.

Czyżewski B., Wkład środowiska poznańsko-gnieźnieńskiego w badania nad literatura wczesnochrześcijańska, „Vox Patrum” 19 (1999) 36-77, s. 97-107.

Dziech J., Gładysz Bronisław Hieronim, w: Polski Słownik Biograficzny, t. 8, WrocławKraków-Warszawa 1959-1960, s. 7.

Gładysz B.H., Cassiodore et l'organisation de l'Ecole Medievale, CT 17 (1936), s. 15-69.

Gładysz B.H., De extremis quibus Seduliana carmina ornatur verborum syllabis inter se consonantibus, Leopoli 1931.

Gładysz B.H., Dogmatyczne teksty w poetyckich utworach Seduliusza. Studium z historii dogmatów V wieku, Poznań 1930.

Gładysz B.H., Dzisiejsza hymnologia kościelna w swym historycznym rozwoju, AK 18 (1932) 30, s. 366-377.

Gładysz B.H., Konstantyn Wielki we współczesnej mu poezji, CT 18 (1937), s. 63-100.

Gładysz B.H., Pierwiastki poklasyczne w traktacie Bedy „,De arte metrica”, „Sprawozdania Poznańskiego Towarzystwa Przyjaciół Nauk” 7 (1933), s. 3-5.

Gładysz B.H., Rzym w poezji Seduliusza, „Kwartalnik Klasyczny” 3 (1929), s. 73-84.

Gładysz B.H., Święty Augustyn u kolebki hymnografii łacińskiej, „Przegląd Teologiczny” 11 (1930), s. 371-398.

Gładyszewski L., Chrystologiczna czy maryjna homilia Hezychiusza, przekład, wstęp, opracowanie, SG 5 (1979-80), s. 245-268.

Gładyszewski L., Maryjne homilie Hezychiusza z Jerozolimy, przekład, wstęp, opracowanie, SG 4 (1978), s. 175-207. 
Grzegorz Wielki św., Moralia. Komentarz do Księgi Hioba, t. 2, księgi VI-X, (tłumaczenie księgi VII, 77-141), ŹrMon 41, Kraków 2006.

Hieronim św., Komentarz do Księgi Jonasza, ŹMT t. 8, wstęp patrystyczny, przekład, opracowanie L. Gładyszewski, Kraków 1998.

Hieronim św., Na Narodzenie Pana, tłumaczenie i komentarz L. Gładyszewski, „Odpowiedzialność" 1 (1992), s. 6.

Kanonicy Kapituły Katedry Gnieźnieńskiej 1918-2009, red. B. Czyżewski, K. Wętkowski, Gniezno 2010, s. 319-327.

Kazania i homilie na święta Pańskie i Maryjne, „Starożytne teksty chrześcijańskie”, t. 1, wstęp, przekłady i redakcja L. Gładyszewski, Lublin 1976.

List „O przeznaczeniu” Andronika Trankwillusa Dalmaty, tłum. L. Gładyszewski, SG 2 (1976), s. 281-295.

Małunowiczówna L., Antologia modlitwy wczesnochrześcijańskiej (pracę przygotował do druku L. Gładyszewski), Lublin 1993.

Pieszczoch S., Ksiądz Józef Nowacki jako patrolog, w: „Ecclesia posnaniensis”. Opuscula Mariano Banaszak septuagenario dedicata Universitatis Mickiewiczianae Facultas Theologica Posnaniae, Poznań 1998, s. 267-272.

Pieszczoch S., Patrologia w Wielkopolsce, szczególnie w Gnieźnie, przed i po II wojnie światowej na tle sytuacji ogólnopolskiej, „Studia Gniesnensia” 11 (1997), s. 335-344.

Prokop K.R., Niedoszly zamyst habilitacji ks. Józefa Nowackiego na Wydziale Teologicznym Uniwersytetu Jagiellońskiego w świetle jego listów do ks. prof. Tadeusza Glem$m y$, „Ecclesia. Studia z dziejów Wielkopolski” 7 (2012), s. 231-264.

Rufina katecheza Symbolu, wstęp, przekład, przypisy L. Gładyszewski, SG 6 (1981), s. 9-64.

Sajdak J., Anonymi Oxoniensis Lexicon in orationes Gregorii Nazianzeni, w: Symbolae grammaticae in honorem Joannis Rozwadowski, I, Cracoviae 1927, s. 153-177.

Sajdak J., Bizantynistyka. Źródła i zarys studiów, Poznań 1933.

Sajdak J., Catullianum (carm. XLIX), „Eos” 23 (1918).

Sajdak J., Co znaczy Geometres kyriotes, „Byzantion” 1931.

Sajdak J., De Cypriani epistularum codice Cracoviensi, „Eos” 20 (1914/1915).

Sajdak J., De Gregorio Nazianzeno poetarum Christianorum fonte, Kraków 1917.

Sajdak J., De Gregorio Nazianzeno posteriorum rhetorum, grammaticorum, lexicographorum fonte, „Eos” 16 (1910), s. 94-99, 18 (1912), s. 1-30.

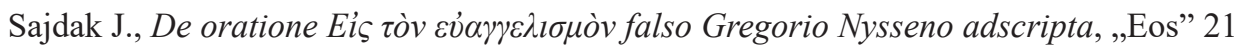
(1916).

Sajdak J., Die Scholiasten der Reden des Gregor von Nazianz, „Byzantinische Zeitschrift” 30 (1930), s. 268-274.

Sajdak J., Filologia klasyczna w Polsce, w: Polska w kulturze europejskiej, praca zbiorowa, t. II, Kraków 1918.

Sajdak J., Franciszek Zabłocki jako tłumacz Horacego, Poznań 1928. 
Sajdak J., Historia critica scholiastarum et commentatorum Gregorii Nazianzeni I, Kraków 1914.

Sajdak J., Ioannes Geometres quatenus feratur paraphrasis Canticorum secundum codicem Paris. Gr. 2743 traditae, „Eos” 1932/33.

Sajdak J., Ioannis Geometrae hymni in SS. Deiparam, „Analecta Byzantina” 1, Poznaniae 1931.

Sajdak J., La poésie lyrique de Jan Geometres comme source historique, w: VI-me Congrès International des Sciences Historiques, Oslo 1928.

Sajdak J., Literatura bizantyńska, w: Wielka literatura powszechna, t. IV, Warszawa 1933, s. 681-760.

Sajdak J., Nazianzenica, „Eos” 15 (1909), s. 122-129, 16 (1910), s. 87-93.

Sajdak J., O bibliotekach rękopisów greckich na wschodzie, „Przegląd Polski” 48 (1914) 192, s. 106-119.

Sajdak J., Piusowi XI. Wielkiemu Papieżowi whołdzie, Poznań 1939 [Papież Wielki, s. 31-40; Pius XI jako uczony, s. 59-61; Bibliografia prac i rozpraw naukowych ks. Achillesa Ratti, s. 61-64].

Sajdak J., Quaestiones Nazianzenicae. Pars prima: Quae ratio inter Gregorium Nazianzenum et Maximum Cynicum intercedat, „Eos” 15 (1909), s. 18-48.

Sajdak J., Rękopisy św. Grzegorza z Nazjanzu w bibliotekach szwajcarskich, „Eos” 17 (1911), s. 193-198.

Sajdak J., Spicilegium Geometreum I, II, „Eos” 32 (1929), s. 191-198.

Sajdak J., Supplementum Rufinianum w ,, Sprawozdaniu Gimnazjum św. Jacka w Krakowie”, Lwów 1918.

Skręt R., Sajdak Jan, w: Polski Słownik Biograficzny, tom 34, Wrocław-Kraków-Warszawa 1992-1993, s. 332-334.

Stawiszyński W., Bibliografia patrystyczna 1901-2004. Polskie ttumaczenia tekstów starochrześcijańskich pierwszego tysiąclecia, Kraków 2005.

Steffen W., Od filologii do patrologii (Jan Sajdak 1882-1967), „Poznańskie Studia Teologiczne" 9 (2000), s. 131-144.

Weiss A., Nowacki Józef, w: Encyklopedia katolicka, t. XIV, Lublin 2010, kol. 27-28. 